work of seismologists has been in the study of individual disturbances for the purpose of determining the principal elements of motion, amplitude, period, direction, and speed of transmission. In this study much has been learned. From the nature of the case we are almost absolutely restricted to an investigation of surface phenomena, and we are soon forced to admit that what goes on at the surface cannot accnrately represent what is going on below. Among other reasons for this conclusion we have, notably, the greatly varying results obtained from the same disturbance at points comparatively very near to each other. The amplitude at one point may be two or three times that at another a few hundred feet away, and not only this, but the periodic times do not agree, and when the maximum acceleration is applied to the disturbance, its so-called intensity or destructiveness will vary greatly within a small area. As a matter of fact, it has long been known that such variations in destructive power do occur in nearly all earthquales. Not only do the above elements vary, but the speed of transmission, when once the surface is reached, is undoubtedly not constant, although we have no reason to believe that it is not approximately so in the rocks through which it is, in the main, transmitted. Most of these irregularities are doubtless due to the non-elastic character of the materials lying near the surface anct to their lack of homogeneity. In spite of their appearance in the phenomena of the surface, it is difficult, if not impossible, to believe that they exist in the rocks below. It is more reasonable to assume that during an earthquake the waves of transmission are, in the main, and until the surface is reached, somewhat regular in their form and approximately constant in certain of their elements. It may also be assumed that in amplitude and periodic time the subterranean wave, although doubtless much less than the surfacewave, cannot differ from it enormously, so that elements of motion obtained by seismometric observations upon the surface may be applied within certain limits to the investigation of the energy involved, the results being considered as rough approximations.

On these assumptions the following calculations have been made :-

Let $\mathrm{A}$ be the area of a portion of a wave-front, and $l$ a length measured at right angles to A. Then formula (5) above, which shows the energy per second across unit area, multiplied by $\frac{\mathrm{A} l}{\mathrm{~V}}$ will evidently express the energy required to generate the waves existing at any moment in the volume $l \mathrm{~A}$. That is

$$
\begin{aligned}
& \frac{2 \pi^{2} a^{2} d \mathrm{~V}}{t^{2}} \cdot \frac{\mathrm{A} l}{\mathrm{~V}} \\
= & \frac{2 \pi^{2} a^{2} d \mathrm{~A} l}{t^{2}} \\
= & \frac{2 \pi^{2} a^{2}}{t^{2}} \cdot m(m=\text { mass of volume } l \mathrm{~A}) \\
= & \frac{1}{2} m v_{1}^{2} .
\end{aligned}
$$

That is to say, the work consumed in generating waves of harmonic type is the same as would be required to give the maximum velocity to the whole mass through which the waves extend. ${ }^{1}$ Sir William Thomson, who was probably the first to apply this principle, in his calculation of the mechanical value of a cubic mile of sunlight, concludes that in the case of a complex radiation this value is more likely to reach twice that of the above expression.

On the assumption that the maximum velocity of the particle is known, we may now apply this formula to the calculation of the energy involved in an earthquake. For this purpose I have selected, first, the Japanese earthquake of Jannary 15 $_{5}, 1887$, which disturbed over 30,000 square miles of territory, and the elements of which were well recorded on the Tokio seismographs. Assuming a mass of 150 pounds per cubic foot, and taking a cubic mile as the volume to be considered, I find that to put it in vibration required the expenditure of $2,500,000,000$ footpounds of energy, and this might be called the "mechanical value of a cubic mile of earthquake." Assuming that an area of 100 miles square, with a mean depth of one mile, was thus in vibration at any one instant of time, which is not improbable considering the lnown rate of transmission and the long duration of the earthquake, the amount of energy thus represented would be $25 \times 10^{12}$ foot-pounds. This energy might be generated by the fall, under the action of gravity, of a cube of rock 1000 feet

I Lord Rayleigh, "Theory of Sound," vol. ii. p. I7., Sir William Thomson on "The Possible Density of the Luminous Medium." on each edge, the mass of which would be 75,000 , oco tons, through a vertical distance of about $\mathrm{I} 66$ feet.

It would be interesting to apply this method to the Charleston earthquake of August 3I, I886. Unfortunately no seismographic records were made, and the elements of motion are largely matters of conjecture. Messrs. Dutton and Hayden, in the report already referred to, express the opinion that in some localities the displacement must have been as much as io inches or I foot. This seems to me improbable, but it may be safe to say that over a considerable area it was as much as I inch. Nothing is known with certainty as to the period of the oscillations, but as it generally increases with the magnitude of the disturbance, it would probably not be grossly incorrect to call it two seconds. Assuming these magnitudes, I find the energy of a cubic mile of the Charleston earthquake, taken near enough to the epicentrum to be disturbed as above, to be equal to $24,000,000,000$ foot-pounds. The speed of transmission of this disturbance has been pretty well determined, by Newcomb and Dutton, to be approximately three miles per second, so that a cubic mile would be disturbed in one-third of a second. To do this would require $\mathbf{1} 30,000,000$ horse-power. Assuming as before that an area about the epicentrum 100 miles square was thus disturbed, the energy involved would $b_{3} 24 \times 10^{13}$ footpounds, and the rate of its expenditure would be that of I,300,000,000,000 horse-power.

All of these numbers can only be regarded as gross approxi. mations. They probably indicate the order of magnitudes in volved, and may be useful until more trustworthy data are furnished.

\section{THE ROYAL HORTICULTURAL SOCIETY}

THE annual general meeting of the Royal Horticultural Society was held on Tuesday, Feloruary I2, at the offices, II 7 Victoria Street, S.W. The Society is to be heartily congratulated on the great improvement which has taken place in its affairs since it quitted the Gardens at South Kensington this time last year. From the Report of the Council, and the speech of Sir Trevor Lawrence, Bart., M.P., President, in moving its adoption, we glean the following particulars. During the past year 657 Fellows have joined the Society, 8I have resigned, and 48 died, the total number of Fellows on the books being now 1636 . The total income from all sources, independent of the "Donation" account ( $£$ II25 5s.), was $£ 36 \mathrm{I} 7$ $8 s .6 d$. ; the total expenditure, $£ 3412 \quad 14 s .4 d$., showing a surplus of 6204 I 4 s. $2 \%$. On January I, 1888, there was a debit balance of $\mathrm{f}_{1152}$, which has been cleared off by the transfer of of $£ 7557$ s. $6 d$. from the "Donation" account, and $£ 396$ I $2 s .6 d$. from current revenue. The total expenditure on the maintenance of the Society's Gardens at Chiswick was $f 15016 s .8 d$., the receipts from the sale of produce, $£ 7377 s$. $6 d$, , brought up by minor items to $£ 8$ Io $4 s$. 3 d., making the net cost of the Gardens to the Society $f 69 \mathrm{I} 2 s$. $5 d$. The income for 1889 is estimated at $£ 3000$, and the expenditure at $£ 2950$. The President referred to the great value to the Society of the services of Mr. Dyer, F.R.S., Director of the Royal Gardens, Kew, and Mr. H. Veitch, who were retiring from the Council owing to the pressure of other engagements, and of Mr. Wilson, F.R.S., and Dr. Hogg, who were retiring after having served the Society well and faithfully during very many years. $\mathrm{He}$ also paid a welldeserved tribute to the energy, ability, judgment, and devotion to their duties, of the Honorary Secretary, the Rev. W. Wilks, and the Treasurer, Mr. D. Morris, Assistant-Director of the Royal Gardens, Kew. During the past year numerous very interesting exhibitions have been held in connection with the fortnightly meetings of the Society in the Drill Hall of the London Scottish Volunteers, James's Street,Buckingham Gate. A magnificent show was held on May 17 and 18 , in the Gardens of the Inner Temple, by the permission of the Treasurer and Benchers, in which, for the first time in the history of such displays, attention was drawn to the excellent horticultural work being done by the market growers of the London district. A conference on apples and pears, held at Chiswick from October 16 to 20, attracted great attention, and the papers read and the discussions raised as to the circumstances and conditions requisite for the successful culivation of these fruits in the British Isles were of great value. The Society propose to hold this year, in addition to a great show in the Temple Gardens on May 30 and 31 , and its usual bi-mon'hly exhibi- 
tions, a national rose conference and show on July 2 and 3 , a great vegetable conference on September 24,25 , and 26 , and a chrysanthemum centenary conference on November 5 and 6 , -all at Chiswick. There will be at the bi-monthly meetings a short lecture and discussion on the plants exhibited, such as was in former years very popular under. the guidance of Dr. Lindley. The Society will revive the publication of its periodical Journal and Proceedings, and carry on at Chiswick extensive triais of various classes of flowering plants, ferns, vegetables, and artificial manures.

Altogether it is gratifying to find that, the unfortunate and costly connection of the Society with South Kensington having been severed, there is a great revival of vigour and vitality and of interest in a Society which has been in existence for nearly a century, is the parent of a vast progeny of kindred institutions throughout the Empire, and has rendered to horticulture services the value of which it is impossible to over-estimate.

\section{SOCIETIES AND ACADEMIES. LONDON.}

Royal Society, January 3r.- "On Isoëtes lacustris, Lirn." By ]. Bretland Farmer, B.A., F.L.S. Communicated by Prof. S. H. Vines, F.R.S.

Many points connected with the development of Isoëtes still remain to be cleared up, and this is especially true of the germination of the macrospore. This structure consists of a mass of protoplasm, which, in perfectly mature spores, is inclosed in a thick envelope, and this envelope is differentiated into six layers, of which the outermost belongs to the episporium, the three within this to the exosporium, and the two innermost to the endosporium. The protoplasm contains very large quan. tities both of oil and starch, and is provided with a large nucleus, in which are embedded certain bodies which appear yellowishbrown in preparations stained with hxmatoxylin, but as to whose nature it is not at present possible to speak definiteiy. During germination, hamatoxylin fails to reveal the presence of a nucleus, and the cytoplasm at this period stains so rapidly and deeply that it is possible that the nuclear substance may be diffused through it. It is when the protoplasm stains thus deeply that the first indication of cell-formation is visible. Its mass is seen to be traversed by " cracks," which divide it into a few large isolated portions, and it is in the direction of these cracks that the cell-walls first appear. The splitling of the protoplasm is doubtless called forth by the methods necessarily used in embedding the spores, but the conclusion that may be drawn from its presence probably is, that the substance destined eventually to form the cell-wall, is present befure the appearance of this structure, and is arranged in a plate-like manner, in such a way as to determine the direction of the cracks referred to. The cells thus formed probably owe their existence to a process similar to that obtaining in the endosperm of many plants, except that, at least so far, I have been unable to detect free nuclei in the first stages. Very soon after cell-formation has begun, these bodies are again very easily seen, especially in the upper part of the young prothallium. Division proceeds with great rapidity in this portion, and the rudiments of the archegonia are laid down. Their origin is similar to that in the Marattiaceæ; superficial cells divide at first once, periclinally, and of the two cells thus formed, the upper gives rise to the neck by further division into four stories, each story being divided crosswise in the usual way; the lower cell forms the central series consisting of oosphere, one neck, and one ventral-canal cell.

Division in the lower part of the prothallium takes place with extreme slowness, and here at least the appearance of free nuclei precedes that of the cell-walls. The cells which arise in this region are readily distinguishable, on account of their large size, from those which owe their origin to the primitive cells in the upper portion of the prothallium, but although further celldivision takes place through out the spore, I am not in a position at present to state exactly how it occurs, or in what relation it stands with regard to the nucleus in these later stages.

Mineralogical Society, January 22.--Mr. R. H. Scott, F.R.S., President, in the chair. - The following papers were read :--On connellite from a new locality, by G. T. Prior.--On pseudomorphs of hæmatite after iron pyrites, by R. H. Solly.On crystals of percylite, caracolite, and an oxychloride of lead (daviesite), from Sierra Gorda, Bolivia, by L. Fletcher.-On the distribution and origin of the liydro-carbons of Ross and Cromarty, by Hugh Miller.

\section{EDINBURGH.}

Royal Society, January 2r.-Prof. Sir Dougla Maclagan, Vice-President, in the chair.-Mr. J. Arthur Thomson cliscussed the history and theory of heredity.-Prof. Haycraft communicated a note, written by himself in conjunction with Dr. E. W. Carlier, on the conversion, by means of friction, of ciliated into stratified squamous epithelium. Specimens in illustration were shown under the microscope.-Prof. Tait read a paper on the virial equation, as applied to the kinetic theory of gases, especially as regards the form of isothermals in the neighbourhood of the critical point. The curves obtained from the new formula, with suitable values of the constants, represent with accuracy the isothermals of carbonic acid gas as obtained experimentally by Andrews. But the chief point of interest in the paper is connected with the question, What portion of the whole kinetic energy of a substance is, in each of its molecular states (i.e. as gas, vapour, liquid, and solid), to be regarded as proportional to the absolute temperature? Prof. Tait gave reasons for believing that it is incorrect to assume, with Van der Waals and Clausius, that the whole kinetic energy determines the absolute temperature. The part which is directly due to inter-molecular forces is at least mainly incommunicable to other bodies, and can thus have little to do with the temperature.-A note, by $\mathrm{Mr}$. R. T. Omond, on a remarkable fog-bow seen from Ben Nevis on December 4, I888, was communicated.-Mr. George Brook described a new type of dimorphism found in certain Antipatharia.-Prof. Crum Brown communicated a paper, by Dr. A. B. Griffiths, on a primitive kidney, or the beginning of a renal system.

\section{Sydney.}

Royal Society of New South Wales, October 3, 1888.--Sir Alfred Roberts, President, in the chair.-The following papers were read:-Considerations of photographic expressions and arrangements, by Baron Ferd. von Mueller, K.C.M.G., F.R.S.-Census of the fauna of the older Tertiary of Australia, by Prof. Ralph Tate.-Notes on the storm of September 2I, r888, by H. C. Russell, F.R.S. Mr. Russell pointed out that, although such cyclonic disturbances seldom visited the coast of New South Wales, experience had proved that they were not unknown, and another such storm of greater dimensions would probably cause considerable havoc in the city of Sydney if the unstable class of buildings so much in vogue were adhered to.- - Some New South Wales tan substances, Part 5, by J. H. Maiden.

November 7.-Mr. IH. C. Russell, F.R.S., Vicc-President, in the chair.-The following papers were read:-Results of observations of Comets I. and II. I888, at Windsor, N.S.W., by John Tebbutt.-Desert sandstone, by the Rev. J. E. Tenison Woods.-On a new self-recording thermcmeler; and notes on the thunderstorm of October 26, I 888 , by H. C. Russell, F.R.S. Three meteorites were exhibited: the first, weighing $35^{\frac{1}{2}}$ pounds, found near Hay, was shown by the Chairman; the second, weighing 137 pounds, found at Thunda, in Queensland, had been received by Prof. Liversidge that afternoon. A preliminary note upon the qualitative analysis of a portion of this meteorite was read before the Society in I886, which showed that it consists essentially of iron and nickel with a little cobalt, sulphur, and phosphorus. The third was exhibited by Mr. C. S. Wilkinson: it weighed $12 \frac{1}{2}$ pounds, and was composed chiefly of iron, of an irregular pear-shape, and was discovered firmly embedded in slate rock on the highest peak of a mountain near the junction of the Burrowa and Lachlan Rivers.

December 5.--Sir Alfred Roberts, President, in the chair. - The Chairman announced that the Council had awarded the Clarke Memorial Medal for 1889 to R. L. J. Ellery, F.R.S., Government Astronomer of Victoria. - The following paper was read:-The Latin verb jubere-a linguistic study, by Dr. John Fraser.-Prof. Liversidge exhibited and described a large collection of New South Wales minerals.

PARIS.

Academy of Sciences, February 4.-M. Des Cloizeaux, President, in the chair.-On the loss of nitrogen during the decay of organic substances, by $M$. Th. Schlosing. The fact that, during decomposition, nitrified organic matter liberates 